\title{
Cimetidine inhibits in vivo growth of human colon cancer and reverses histamine stimulated in vitro and in vivo growth
}

\author{
W J Adams, J A Lawson, D L Morris
}

\begin{abstract}
The effect of histamine and cimetidine on the growth of four human colon cancer cell lines was studied. Histamine significantly stimulated the uptake of tritiated thymidine in vitro in a dose dependent manner, to a maximum of $120 \%$ and $116 \%$ of controls for C170 and LIM2412, respectively. This effect was antagonised by cimetidine, but not diphenhydramine. Histamine also stimulated a dose dependent increase in cyclic adenosine monophosphate accumulation in $\mathrm{C170}$ cells, antagonised by cimetidine. When grown as subcutaneous xenografts in Balb/c nu/nu mice, cimetidine had a significant inhibitory effect on the same two cell lines. The final volume of $\mathrm{C} 170$ tumours in animals given cimetidine was $44 \%$ of controls. This response was dose dependent, plateauing at a cimetidine dose of $50 \mathrm{mg} / \mathrm{kg} / \mathrm{day}$. The final volume of LIM2412 tumours in animals given cimetidine was $60 \%$ of controls. Histamine administered locally by a mini-osmotic pump stimulated C170 tumour growth to $164 \%$ of controls, was antagonised by cimetidine at a dose of $200 \mathrm{mg} / \mathrm{kg} / \mathrm{day}$, but not by lower concentrations. Histamine has a trophic effect on at least two colorectal cancer cell lines in vivo and in vitro. As this effect is antagonised by cimetidine, it may be mediated via tumour histamine type 2 receptors.
\end{abstract}

(Gut 1994; 35: 1632-1636)

Cimetidine has been shown to inhibit the growth of several types of tumours in animals ${ }^{1-4}$ and to induce tumour regression in man. ${ }^{5}$ One controlled trial in gastric cancer has shown a significant survival advantage in patients who received postoperative cimetidine. ${ }^{6}$ These effects were largely attributed to the important effects of cimetidine on the immune function.

Our recent finding that cimetidine inhibited the growth of carcinogen induced colonic tumours in rats, with corresponding reductions in the cellular proliferative indices, ${ }^{7}$ led us to investigate further the role of histamine in colonic cancer. The present study examines the effect of histamine and cimetidine on colorectal cancer cell lines to determine the presence of a direct non-immunological effect in this type of malignancy.

\section{Methods}

MATERIALS

Four human colonic adenocarcinoma cancer cell lines were studied. $\mathrm{C} 170^{8}$ and $\mathrm{LoVo}^{9}$ were gifted by CRC Laboratories, Nottingham, UK and LIM2412 and LIM2405 ${ }^{10}$ were gifts from the Ludwig Institute, Melbourne, Australia. All cell lines were maintained in RPMI plus $10 \%$ fetal calf serum (FCS) (Cytosystems Pty Ltd, Australia) at $37^{\circ} \mathrm{C}$ in $5 \% \mathrm{CO}_{2}$.

Chemicals used were: cimetidine (Smithkline Beecham, Australia); diphenhydramine (Aldrich Pty Ltd, USA); isobutylmethylxanthine (IBMX), thymidine, and histamine hydrochloride (Sigma Chemical Co, St Louis, USA); ${ }^{3} \mathrm{H}$-methylthymidine (Dupont, USA) and; Hams F12/MEM media (Cytosystems Pty Ltd, Australia).

\section{CELL PROLIFERATION ASSAY}

Tumour cells were suspended at a concentration of $1 \times 10^{5}$ cells $/ \mathrm{ml}$ in RPMI-1640 with $10 \%$ FCS, distributed onto a 96 well microtitre plate and incubated at $37^{\circ} \mathrm{C}$ for 24 hours. The cells were then synchronised by a further 24 hours' incubation in a $0.6 \mathrm{mmol} / 1$ solution of thymidine in serum free RPMI. The supernatant was then replaced with Hams F12/MEM media containing the test drugs (histamine, diphenhydramine, and cimetidine) at a range of concentrations $\left(1 \times 10^{-10} \mathrm{M}\right.$ to $1 \times 10^{-6} \mathrm{M}$ ) in a volume of $200 \mu \mathrm{l}$. Control wells contained media alone. After the addition of $50 \mu \mathrm{l}$ of $0 \cdot 1 \mu \mathrm{Ci}$ of ${ }^{3} \mathrm{H}$-methylthymidine, the cells were incubated for 24 hours. After this, they were harvested, washed, and counted using a Packard scintillation beta counter (model B4430) using a DPM option (modified from Kusyk et al $1986^{11}$ ).

Each concentration was tested in quadruplicate and repeated on three separate occasions. Results are expressed as a mean (SEM) percentage of the control. A one way analysis of variance (ANOVA) was used to compare treated with control wells.

\section{QUANTIFICATION OF STIMULATED} INTRACELLULAR CYCLIC ADENOSINE MONOPHOSPHATE (CAMP)

C170 cells were suspended in serum free RPMI-1640 containing $0.5 \mathrm{mM}$ IBMX at a concentration of $1.25 \times 10^{5}$ cells $/ 250 \mu$ l. Aliquots $(125 \mu \mathrm{l})$ of histamine were added in a 
range of concentrations from $1 \times 10^{-7} \mathrm{M}$ to $1 \times 10^{-3} \mathrm{M}$, with or without the addition of a histamine antagonist at a concentration of $1 \times 10^{-4} \mathrm{M}$. The cells were then incubated for 10 minutes at $37^{\circ} \mathrm{C} .{ }^{12}$ The incubation was terminated by the addition of $0.5 \mathrm{ml}$ of 0.001 $\mathrm{M} \mathrm{HCl}$ in chilled ethanol to fix the cells and allow for cAMP extraction. The suspension was mixed, then centrifuged for 15 minutes at $15000 \mathrm{rpm}$. Some $0.4 \mathrm{ml}$ of supernatant was drawn off and the contents were extracted using a Speed Vac Concentrator (Savant Instruments, NY, USA).

After reconstitution in $2 \mathrm{ml}$ of the buffer solution provided, the concentration of cAMP present was measured using a monoclonal antibody based kit (Amersham, UK). Results were expressed in fmol of cAMP/10 $10^{5}$ cells, after corrections were made for the dilutions performed during the assay. Each drug concentration was measured in triplicate and repeated in two experiments. The data were non-parametric and were analysed using a Kruskal-Wallis test.

\section{XENOGRAFTS}

Six to 10 week old male Balb/c $n u / n u$ mice (ANSTO, Lucas Heights, Australia) were used as tumour hosts. Four separate experiments were carried out.

In the first experiment, $1 \mathrm{~mm}^{3}$ fragments of tumours developed from each cell line were subcutaneously implanted into anaesthetised animals (Hypnorm, Janssen Pharmaceutica, Australia). The mice were then randomly allocated to either treatment or control groups of 10 animals for each cell line. Control animals had free access to autoclaved deionised drinking water. For the animals in the treatment group, the water contained the histamine type 2 receptor antagonist, cimetidine, at a concentration of $0.4 \mathrm{mg} / \mathrm{ml}$. As nude mice have previously been shown to drink an average of $5(0.6) \mathrm{ml} /$ day $^{2}$ (as confirmed in our own laboratory), this would produce an oral intake of cimetidine that approximate to 100 $\mathrm{mg} / \mathrm{kg} /$ day. $^{2}$ Treatment began on the day of tumour implantation. The experiment ended when the tumours began to ulcerate, usually between the $21 \mathrm{st}$ and 28 th days. The drinking water was renewed every three days until the end of the experiment. ${ }^{2}$

After implantation, most xenografts grew into single spherical or ovoid tumours. The two greatest tumour perpendicular diameters were measured three times weekly with vernier callipers, and their volumes $(\mathrm{V})$ were calculated by the formula $\mathrm{V}=0.5$ length $\times$ (width). ${ }^{2}{ }^{13}$ In a few cases the tumours became bosselated, with two or more foci of tumour growth. In these cases each ovoid component of the tumour was measured separately, using the method described above, and the total volume was calculated from their sum. Those animals which failed to develop a tumour mass were excluded from analysis.

At the end of the experiment, all mice were killed by intraperitoneal dose of pentabarbitone sodium (Lethobarb, Virbas Pty Ltd, Australia). Tumours were harvested and fixed in $10 \%$ formalin for histological examination.

In the second experiment, xenografts were produced by a subcutaneous injection in the left flank of each animal of $1 \times 10^{6}$ C170 cells suspended in $100 \mu$ l of RPMI1640. Immediately after this injection, the animals were randomised to treatment
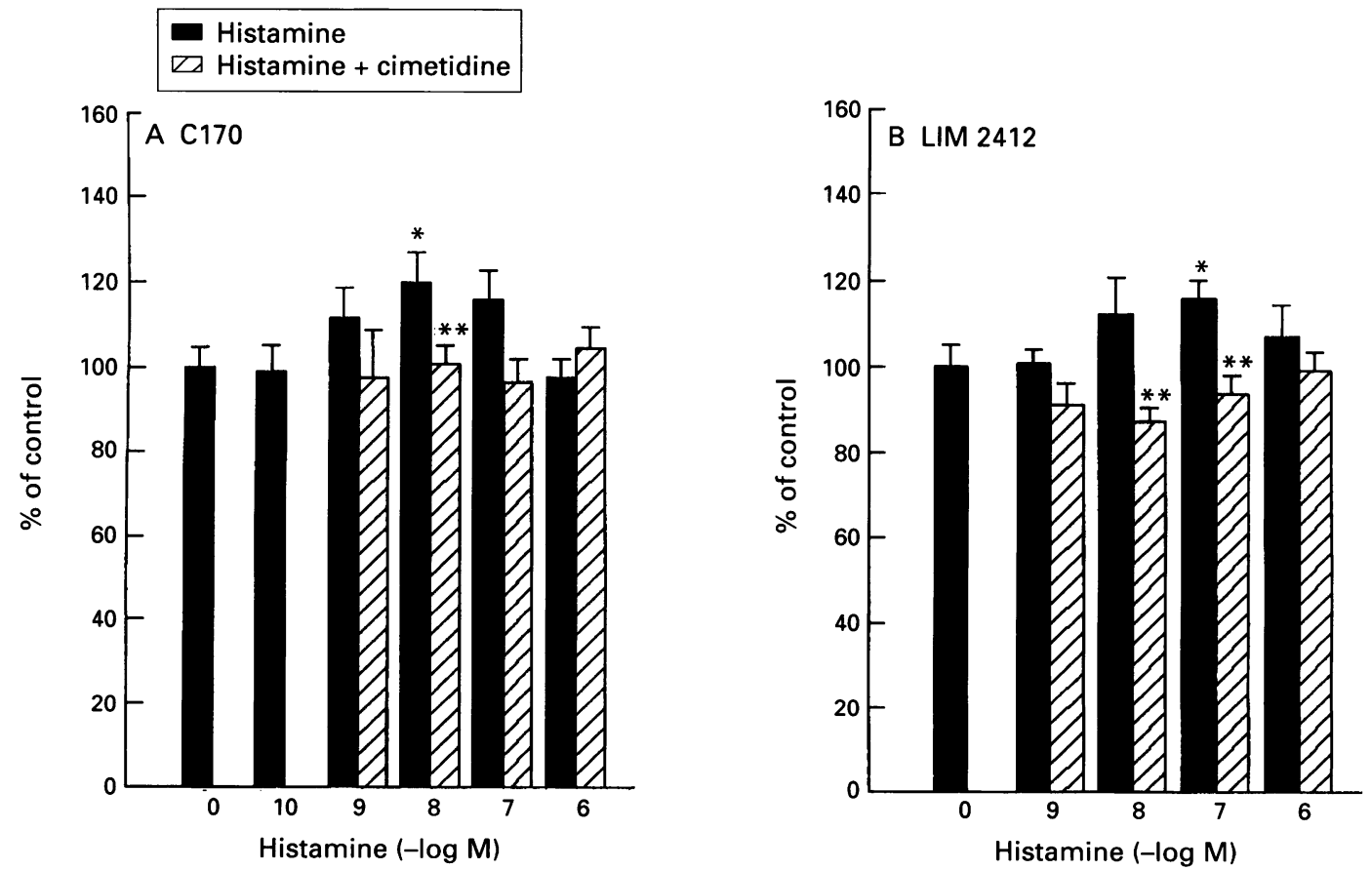

Figure 1: The effect of histamine on in vitro proliferation with and without the addition of cimetidine at $100 \times$ the histamine concentration. Combined results from three experiments performed in quadruplicate. Results are expressed as a percentage of mean ${ }^{3} \mathrm{H}$-methyl thymidine uptake relative to controls and were compared using ANOVA. Error bars represent the SEM. Those marked with a single asterisk were significantly greater than controls $(p<0 \cdot 05)$, those marked with a double asterisk were significantly less than those treated with histamine alone. $(A)$ Cell line C170: (B) Cell line LIM2412. 


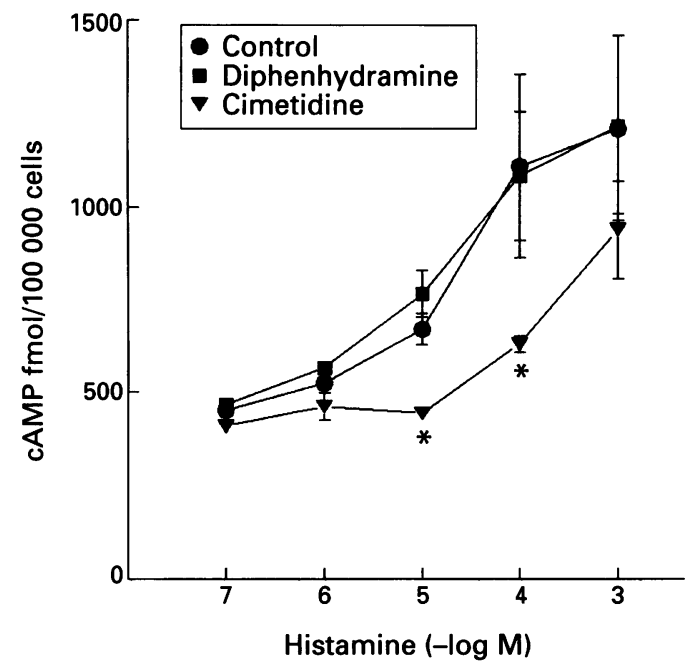

Figure 2: The effect of histamine on intracellular levels of cyclic adenosine monophosphate cAMP in $C 170$ cells, with and without the addition of cimetidine at a concentration of $10^{-4} \mathrm{M}$. Combined results from two experiments performed in triplicate. Results are expressed as mean fmol cAMP $10^{5}$ cells and error bars represent the SEM. Raw data were compared using a Kruskal-Wallis test. ${ }^{\star} p<0.05$.

groups receiving cimetidine in the drinking water at concentrations of $0,10,25$, or $50 \mathrm{mg} / \mathrm{kg} /$ day. The experiment was then repeated with cimetidine concentrations of 0 , 50,100 , and $200 \mathrm{mg} / \mathrm{kg} /$ day and was otherwise identical to the first experiment.

In the third experiment, each animal had a 14 day mini-osmotic pump (Model 2002, Alza Corporation, Palo Alto, USA) implanted subcutaneously in the left flank under anaesthesia. A suspension of $1 \times 10^{6} \mathrm{C} 170$ cells in $100 \mu$ l of RPMI-1640 was then injected subcutaneously in the region of the pump's orifice. In one group of 10 animals, the pump contained $0.9 \%$ phosphate buffered saline (PBS) and the mice received no cimetidine. In the remaining three groups of 10 animals, the pump contained histamine at a concentration of $1 \times 10^{-2} \mathrm{M}$ in

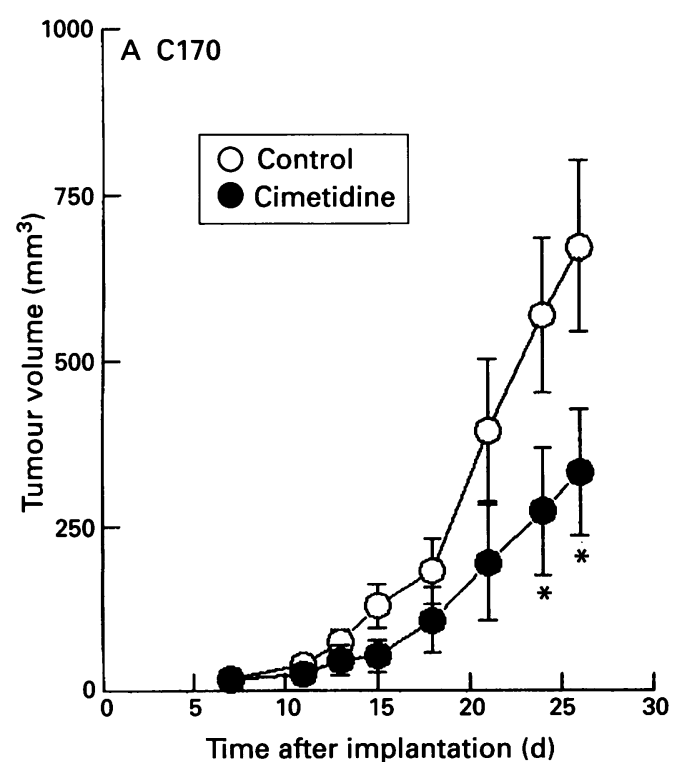

PBS, delivered at a rate of $1 \times 10^{-10} \mathrm{~mol} / \mathrm{min}$. One group received no cimetidine in the drinking water, one group received cimetidine at a rate of $50 \mathrm{mg} / \mathrm{kg} /$ day and another cimetidine at a rate of $200 \mathrm{mg} / \mathrm{kg} /$ day. All pumps were replaced after 14 days. The experiment was otherwise identical to experiments 1 and 2 .

In the fourth experiment tumours were inoculated as in experiment 2. Animals were randomly allocated to act as controls or to receive the histamine type 1 receptor antagonist, diphenhydramine, in the drinking water at concentrations of $0.02 \mathrm{mg} / \mathrm{ml}$ or $0.08 \mathrm{mg} / \mathrm{ml}$, approximating to daily doses of $5 \mathrm{mg} / \mathrm{kg}$ and $20 \mathrm{mg} / \mathrm{kg}$ respectively. Concentrations of diphenhydramine of $50 \mathrm{mg} / \mathrm{kg} /$ day and $100 \mathrm{mg} / \mathrm{kg} /$ day had previously been found in our laboratory to be toxic in these animals. There were 10 animals in each group and the experiment proceeded as for experiments 1 and 2 .

In each case the data from treated and untreated groups were compared using a Kruskal-Wallis test.

\section{Results}

\section{CELL PROLIFERATION ASSAY}

Histamine produced a dose dependent stimulation of cell proliferation in the cell lines C170 (Fig 1A) and LIM2412 (Fig 1B). A bell shaped curve of response to histamine was seen, with maximal stimulation occurring at histamine concentrations of $1 \times 10^{-8} \mathrm{M}$ and $1 \times 10^{-7} \mathrm{M}$ for $\mathrm{C} 170$ and LIM2412 respectively. For both these cell lines the stimulatory effect of histamine was significantly antagonised in the presence of $100 \times$ molar excess of cimetidine. The addition of a $100 \times$ excess of diphenhydramine did not alter the response to histamine of either of these cell lines (data

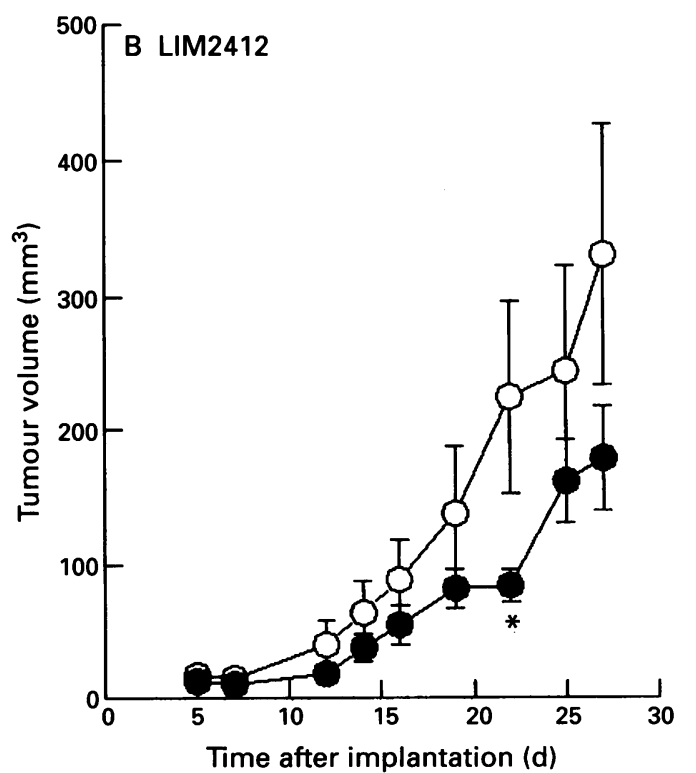

Figure 3: The growth of human colon cancer xenografts implanted subcutaneously in Balb/c nu/nu mice. Treated animals received cimetidine in the drinking water at a dose of $100 \mathrm{mg} / \mathrm{kg} /$ day. Points represent mean tumour volumes, error bars represent the SEM. Tumour volumes were compared using a Kruskal-Wallis test; those marked with an asterisk were significantly less than controls $(p<0 \cdot 05)$. (A) Cell line $C 170$ xenografts: control $n=6$; cimetidine $n=8$. (B) Cell line LIM2412 xenografts: control $n=5$; cimetidine $n=7$. 

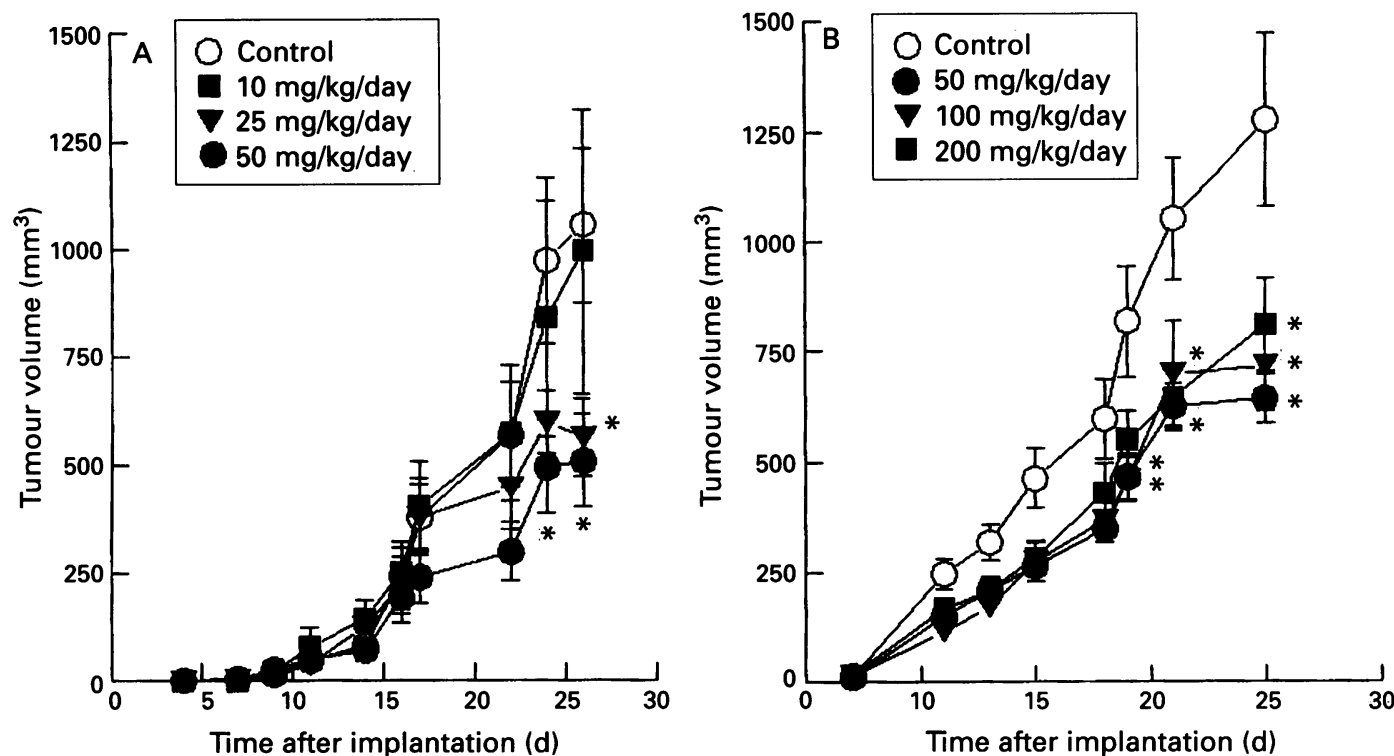

Figure 4: The effect of a range of cimetidine doses on the growth of $C 170$ xenografts. Points represent mean tumour volumes, error bars represent the SEM. Tumour volumes were compared using a Kruskal-Wallis test; those marked with an asterisk were significantly less than controls $(p<0 \cdot 05)$. (A) Control $n=8 ;$ cimetidine $50 \mathrm{mg} / \mathrm{kg} /$ day $n=8$; cimetidine $25 \mathrm{mg} / \mathrm{kg} /$ day $n=7$; cimetidine $10 \mathrm{mg} / \mathrm{kg} /$ day $n=8$. (B) Control $n=21$; cimetidine $200 \mathrm{mg} / \mathrm{kg} /$ day $n=15$, cimetidine $100 \mathrm{mg} / \mathrm{kg} /$ day $n=16$; cimetidine $50 \mathrm{mg} / \mathrm{kg} /$ day $n=16$.

not shown). Cimetidine did not effect the basal rate of proliferation of either of these cell lines in the absence of histamine (data not shown).

Neither histamine nor cimetidine had any significant effect on the cell lines LIM2405 or LoVo (data not shown).

\section{QUANTIFICATION OF STIMULATED}

INTRACELLULAR CAMP

Histamine stimulated a dose dependent increase in intracellular cAMP production in C170 cells to a maximum of $275 \%$ of basal levels (Fig 2). This effect was antagonised by cimetidine but not by diphenhydramine.

\section{XENOGRAFTS}

No animal developed macroscopic deposits of metastatic disease in the lungs, liver, or other

Figure 5: The effect of exogenous histamine delivered at a rate of $10^{-10}$ mol/min on C170 xenografi growth, with and without treatment with oral cimetidine. Points represent mean tumour volumes, error bars represent the SEM. Tumour volumes were compared using a Kruskal-Wallis test. Tumours marked with a single asterisk were significantly greater than controls. Tumours marked with a double asterisk were significantly less than those in animals receiving

histamine without

cimetidine $(p<0 \cdot 05)$.

Control $n=8 ;$ subcutaneous histamine $1 \times 10^{-10}$ $\operatorname{mol} / \min n=9$;

subcutaneous histamine

plus cimetidine 200

$m g / k g / d a y ~ n=10$;

subcutaneous histamine

plus cimetidine

$50 \mathrm{mg} / \mathrm{kg} /$ day $n=8$. organs. Final animal body weights did not

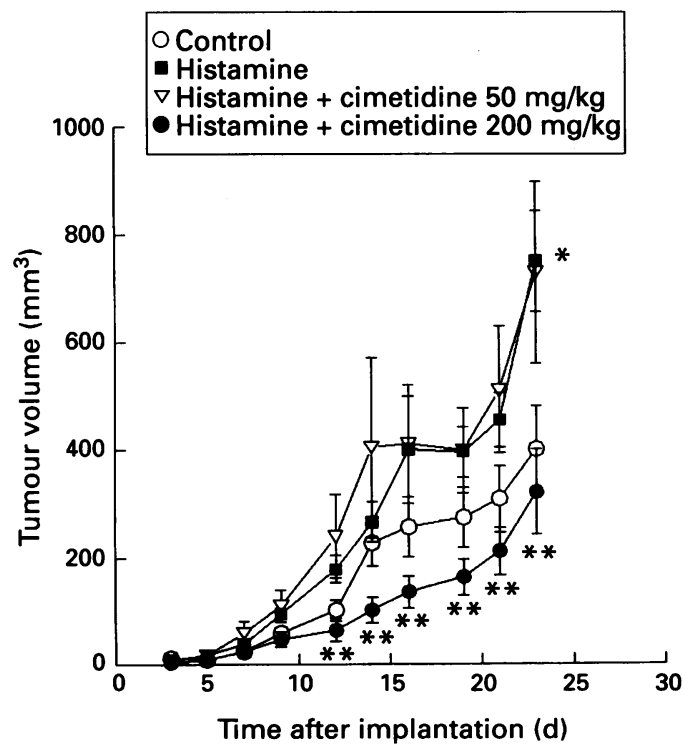

significantly differ between control animals and those receiving either cimetidine or histamine and neither did the proportion of animals in which tumours were successfully induced.

In the first experiment, the growth of both C170 and LIM2412 tumours was significantly inhibited by cimetidine at a dose of 100 $\mathrm{mg} / \mathrm{kg} /$ day, with reductions in the final mean tumour volumes to $43.5 \%$ and $59.5 \%$ of controls, respectively (Fig 3). The remaining two cell lines, LIM2405 and LoVo, were not significantly effected (data not shown).

The effect of cimetidine on C170 tumour growth was dose dependent, plateauing at a dose of $50 \mathrm{mg} / \mathrm{kg} /$ day (Fig 4).

Diphenhydramine, at doses of $5 \mathrm{mg} / \mathrm{kg} /$ day and $20 \mathrm{mg} / \mathrm{kg} / \mathrm{day}$, did not significantly effect tumour growth (data not shown).

Exogenous histamine produced an increase in the final mean tumour volume to $163.6 \%$ of control (Fig 5). This effect was completely reversed by cimetidine at a dose of 200 $\mathrm{mg} / \mathrm{kg} /$ day, but not at $50 \mathrm{mg} / \mathrm{kg} /$ day.

\section{TUMOUR HISTOLOGY}

Histological sections of resected tumours of each cell line showed poorly differentiated tumours with little surrounding cellular inflammatory reaction in the host tissues. Larger tumours exhibited central necrosis. There was no macroscopic difference between tumours from treated and untreated animals.

Discussion

These experiments have shown that cimetidine has an inhibitory effect on both in vivo and in vitro growth of two or four human colon cancer cell lines tested.

We have already shown that cimetidine inhibits the growth of carcinogen induced colorectal cancer. ${ }^{7}$ Transient in vivo inhibition 
of xenografts of two colon cancer cell lines, has also been described previously. ${ }^{14}$ In addition, cimetidine has been found to have an inhibitory effect on several other tumour types ${ }^{1-4}$ and has induced a clinical response in human cancers. ${ }^{5}$ 6 It has been thought that cimetidine acts through immunostimulation ${ }^{1-4} 15-17$ mediated via histamine receptors on lymphocyte suppressor cells; ${ }^{1819}$ however, the results of our experiments in vitro suggest that a direct inhibitory effect on tumour cell proliferation is also present, for at least some tumours.

The fact that histamine stimulation of in vitro growth for both C170 and LIM2412 is antagonised by cimetidine, but not diphenhydramine, suggests that this is an $\mathrm{H}_{2}$ receptor phenomenon. This is confirmed by histamine's stimulation of intracellular cAMP production in $\mathrm{C} 170$ cells, again antagonised by cimetidine, as these receptors are known to be linked to adenylate cyclase. ${ }^{20}$ Functional $\mathrm{H}_{2}$ receptors have been reported on other tumour types, including gastric cancer ${ }^{21}$ and melanoma. ${ }^{22}$

A recent paper by Watson et $a l^{23}$ found that, in contrast to our own results, histamine did not stimulate the in vitro proliferation of $\mathrm{C} 170$, but did stimulate the growth of the gastric cancer cell line, MKN45, both in vivo and in vitro. Histamine was found to stimulate intracellular cAMP production in MKN45, but not C170, suggesting the presence of tumour $\mathrm{H}_{2}$ receptors on the former cell line as the mechanism for histamine's action. The effect of histamine on the rate of cellular proliferation of $\mathrm{C} 170$ in our model was modest, as was the volume of production of cAMP. The difference in findings between our groups may represent differences in cell characteristics that have arisen after a period of separate evolution in different laboratories, as well as differences in assay technique. It would be interesting to see the effect of cimetidine treatment of xenografts on Watson's C170 cells, as this experiment was not reported to have been performed.

The histamine pump experiments on our C170 xenografts showed a dose effect of histamine in vivo. While exogenous histamine stimulated basal tumour growth, it also led to an increase in the required dose of cimetidine needed to inhibit tumour growth. This suggests a direct antagonism of histamine's effect by cimetidine in vivo, again supporting the role of $\mathrm{H}_{2}$ receptors. These $\mathrm{H}_{2}$ receptors may either be those located on the tumour cells themselves or those on immunocompetent cells of the host, or both. This stimulatory effect of high local histamine concentrations may be one explanation for the importance of tumour associated mast cells. Fisher et al 24 have shown that the number of mast cells present in rectal cancer is prognostic - if there were more than four mast cells/high power field, survival was significantly poorer. Tumour mast cells have been shown to effect tumour cellular kinetics, with a higher proportion of PCNA positive tumour cells located close to the mast cells, suggesting a more rapid cell turnover, than tumour cells more distant. ${ }^{25}$
These experiments have shown that histamine has a trophic effect on at least two colorectal cell lines which can be antagonised by the $\mathrm{H}_{2}$ antagonist, cimetidine. The response of these cell lines to histamine in vitro points to the importance of functional, tumour borne $\mathrm{H}_{2}$ receptors.

This work was supported by the Florence Cancer Research Fellowship, awarded by the Royal Australasian College of Surgeons, and Smithkline Beecham, Australia.

1 Obsand M, Shen Y-J, Shlesinger M, Brown A, Hamilton D, Cohen E. Successful immunotherapy with cimetidine in mice. Lancet 1981; i: 636-8.

2 Gifford M, Ferguson R, Voss B. Cimetidine reduction of tumour formation in mice. Lancet 1981; i: 638-9.

3 Bartholeyns J, Bouclier M. Involvement of histamine in growth of mouse and rat tumours: antitumoral propertie of monofluoromethylhistidine, an enzyme activated irreversible inhibitor of histidine decarboxylase. Cancer Res 1984; 44: 639-45.

4 Kikuchi Y, Oomori K, Kato K. Effects of cimetidine on growth and immune function in nude mice bearin human ovarian carcinoma. $\mathcal{f}$ Natl Cancer Inst 1985; 74: 495-8.

5 Armitage JO, Sidner RD. Antitumour effect of cimetidine. Lancet 1979 ; i: 882-3.

6 Tonnesen H, Knigges U, Bulow S, Damm P, Fischerman $K$, Hesselfeld $P$. Effect of cimetidine on survival after gastric cancer. Lancet 1988; ii: $990-1$.

7 Adams WJ, Lawson JA, Nicholson SE, Cook TE, Morris DL. The growth of carcinogen induced colon cancer in rats is inhibited by cimetidine. Eur F Surg Oncol 1993; 19: 332-5.

Durrant LG, Robins RA, Pimm MV, Armitage NC, Brown A, Baldwin RW, et al. Antigenicity of newly established colorectal carcinoma cell lines. Br $\mathcal{f}$ Cancer 1986; 53: 37-45.

9 Drewinko B, Romsdahl MM, Yang LY, Ahearn MJ, Trujillo JM. Establishment of a human carcinoembryonic antigen-producing colon adenocarcinoma cell line. Cancer Res 1976; 36: 467-72.

10 Whitehead RH, Zhang HH, Hayward IP. Retention of tissue-specific phenotype in a panel of colon carcinoma tissue-specific phenotype in a panel of colon carcinoma Ciol 1992; 70: 227-36.

11 Kusyk CJ, McNiel NO, Johnson LR. Stimulation of growth of a colon cancer cell line by gastrin. Am $\mathcal{F}$ Physiol 1986 251: G597-601

12 Shahin E, Gespach C, Bodere H. Selective disappearance of histamine $\mathrm{H}_{2}$ receptor activity in the human gastric cance cell line HGT-1 after short term or chronic treatment by histamine or its $\mathrm{H}_{2}$ antagonists. Agents Actions 1985; 16 195-8.

13 Euhus D, Hudd C, LaRegina M, Johnson F. Tumour measurement in the nude mouse. F Surg Oncol 1986; 31 229-34.

14 Tutton $P$, Steel G. Influence of biogenic amines on the rowth of ren. Inted human colorectal carcinomas. Br $\mathcal{F}$ Cancer 1979; 40: 743-9.

15 Kumar A, Cleveland R. Immunoregulatory effect of cimetidine: inhibition of suppressor effector cell function in vivo. Immunopharmacol Immunotoxicol 1988; 10: 327-32.

16 Khan M, Keaney K, Melmon K, Clayberger C, Krensky A Histamine regulates the generation of human cytolytic ' lymphocytes. Cell Immunol 1989; 121: 60-73.

17 Gifford R, Tilberg A. Histamine type-2 receptor antagonist immune modulation II. Cimetidine and ranitidine increase interleukin-2 production. Surgery 1987; 102: 242-7.

18 Shibata M, Hoon D, Okun E, Morton D. Modulation of histamine type II receptors on CD8 T cells by interleukin2 and cimetidine. Int Arch Allergy Immunol 1992; 97: 8-16.

19 Griswold D, Alessi S, Badger A, Poste G, Hanna N. Inhibition of $\mathrm{T}$ suppressor cell expression by histamine type $2\left(\mathrm{H}_{2}\right)$ receptor antagonists. F Immunol 1984; 132: 3054-7.

20 Hill S. Distribution, properties and functional characteristics of three classes of histamine receptor. Pharmacol Rev 1990; 42: 45-83.

21 Laboise C, Augeron C, Couturier-Turpin M, Gespach C, Cheret A, Potet F. Characterization of a newly established human gastric cancer cell line HGT-1 bearing histamine humas

22 Whitehead RJ, Taylor D, Evanson J, Hart I, Woolley D. Demonstration of histamine $\mathrm{H}_{2}$ receptors on human melanoma cells. Biochem Biophys Res Comm 1988; 151: melanom

23 Watson SA, Wilkinson LJ, Robertson JFR, Hardcastle JD. Effect of histamine on the growth of human gastrointestinal tumours: reversal by cimetidine. Gut 1993; 34: 1091-6.

24 Fisher ER, Park SM, Rockette H, Jones J, Caplon R, Fisher B. Prognostic significance of eosinophils and mast cells in rectal cancer. Hum Pathol 1989; 20: 159-63.

25 Jeziorska M, Haboubi NY, Schofield PF, Woolley DE. Mast cell distribution and tumour cell proliferation in colonic carcinoma. Gut 1993; 34 (suppl 1): S5. 